\title{
PERANAN ALGORITMA PEMROGRAMAN DALAM SISTEM OPERASI KOMPUTER
}

\author{
Nur Shakila Amanda \\ Pendidikan Matematika Fakultas Ilmu Tarbiyah dan Keguruan Universitas Islam Negeri \\ Sumatera Utara, Uinsu. \\ Email : Shakilaamanda99@gmail.com
}

\begin{abstract}
Computers are very popular in today's modern era. Various ages from young to old already understand how to use a computer. Not infrequently several schools or universities from elementary, junior high, and high school have used computers in the school environment through practicum. Do not forget also that the computer has networks that are very, very important to know, one of which is algorithms and programming. As it is known that the algorithm is one of the syllables that originally started from mathematics and programming that started from a computer or cellular network. Therefore, its use can be linked to a role in the operating system in which there is a programming algorithm. The operating system is a very important role in various devices that exist in the computer. Because basically a computer is also based on an operating system which is definitely very sophisticated in its development which is none other than the system software (software), hardware (hardware) and users (brainware). An example of software is Microsoft Office which is very often used by students or workers.
\end{abstract}

Keywords : Computer; network ; system ; operation ; algorithm ; programming

\begin{abstract}
Abstrak
Komputer sangat terkenal di era zaman modern sekarang. Berbagai umur pun dari muda hingga yang tua sudah memahami bagaimana cara menggunakan sebuah komputer. Tak jarang beberapa sekolah ataupun universitas dari SD,SMP,dan SMA sudah menggunakan komputer di lingkungan sekolah melalui praktikum. Tak lupa pula bahwa di dalam komputer memiliki jaringan-jaringan yang amat sangat penting diketahui, salah satunya yaitu algoritma dan pemograman. Seperti yang diketahui bahwa algoritma merupakan salah satu suku kata yang awalnya bermula dari matematika dan pemograman yang bermula dari sebuah komputer ataupun jaringan seluler. Maka dari itu penggunaannya bisa dihubungkan menjadi salah satu peranan dalam sistem operasi dimana didalamnya terdapat algoritma pemograman. Sistem operasi merupakan peranan yang sangat penting dalam berbagai perangkat-perangkat yang ada dalam komputer. Karena pada dasarnya sebuah komputer juga didasarkan oleh sebuah sistem operasi yang sudah pasti sangat canggih perkembangannya yang tak lain dan tak bukan yaitu sistem perangkat lunak (software), perangkat keras (hardware) dan pengguna (brainware). Contoh dari perangkat lunak (software) yaitu microsoft office yang sangat sering sekali dipakai oleh kalangan pelajar ataupun pekerja.
\end{abstract}

Kata Kunci : Komputer ; jaringan ; sistem ; operasi ; algoritma ; pemrograman 


\section{PENDAHULUAN}

Sistem operasi merupakan peranan yang sangat penting dalam berbagai perangkat-perangkat yang ada dalam komputer. Karena pada dasarnya sebuah komputer juga didasarkan oleh sebuah sistem operasi yang sudah pasti sangat canggih perkembangannya yang tak lain dan tak bukan yaitu sistem perangkat lunak (software), perangkat keras (hardware) dan pengguna (brainware).

Contoh dari perangkat lunak (software) yaitu microsoft office yang sangat sering sekali dipakai oleh kalangan pelajar ataupun pekerja. Dimana, microsoft office tersebut banyak menyediakan fitur untuk mengerjakan suatu materi atau pekerjaan dan sangat wajib ada didalam sebuah perangkat komputer. Lalu salah satu contoh dari perangkat keras (hardware) adalah keyboard dan mouse yang sebenarnya juga sangat sering digunakan di kehidupan sehari-hari apalagi jika menggunakan komputer pasti tidak enak jika tidak menggunakan keyboard ataupun mouse dan seluruh kegiatan jadi amat sangat susah untuk mencapai tujuannya. Dan untuk yang terakhir yaitu brainware atau pengguna, ibarat pribahasa (tak kenal maka tak sayang) yang jika dihubungkan kedalam penulisan ini, maka jika ada sebuah komputer maka didalamnya terdapat perangkat-perangkat dan sistem operasinya. Lalu jika sudah terdapat seluruh komponennya dan bisa menghasilkan sebuah komputer tidaklah berguna jika tidak ada penggunanya. Oleh karena itu komputer digunakan untuk membuat orang-orang atau masyarakat bisa mencoba dan menggunakan perangkat komputer tersebut.
Sistem Operasi komputer juga sudah sangat banyak tersebar didalam beberapa perangkat, tak hanya komputer, smartphone atau pun ipad sudah hampir sama seperti sistem-sistem yang ada pada komputer. Bedanya hanya saja pada bagian bentuk yang lebih kecil dan kemungkinan hrga nya tidak jauh berbeda. Hal tersebut sering sekali membuat branware (pengguna) bingung untuk memilih yang mana dikarenakan banyak produk yang memiliki sistem tersebut sangat mudah terjangkau dan pastinyasangat bagus bila digunakan.

Tetapi tak heran jika masih banyak yangmengalami masalah dalam penggunaan sistem operasi komputer ini. Salah satunya setiap tahun sudah pasti akan mengeluarkan produk-produk baru yang pastinya lebih bagus dari sebelumnya dan membuat pengguna versi lama kesulitan dalam mengupgrade ulang produk nya. Hal tersebut bisa membuat versi produk komputer menjadi lebih lambat dan harus memiliki versi yangterbaru agar produk tetap bagus tanpa adanya masalah.

\section{KAJIAN LITERATUR}

\section{Pengertian Algoritma}

Algoritma adalah prosedur langkah demi langkah untuk suatu perhitungan. Algoritma digunakan untuk penghitungan, pemrosesan data dan penalaran otomatis. Jadi algoritma bisa dibilang sebuah jalan untuk mencapai tujuannya. Algoritma dilakukan dari sebuah prosedur langkahlangkah yang sudah dilakukan agar bisa mencakup materi dan mendapatkan jawabannya. Dalam matematika, banyak sekali materi seperti algoritma misalnya pecahan, kita harus mengikuti beberapa 
langkah mengerjakannnya lalu agar bisa mendapatkan hasil akhirnya. Sedangkan algoritma ini bisa dihubungkan kedalam pemrograman seperti perangkat komputer dan lain-lain.

Seperti yang kita ketahui juga bahwa banyak sekali materi pada matematika bisa dikaitkan atau sangat berhubungan kedalam kehidupan seharihari. Oleh karena itu kesimpulannya ialah algoritma merupakan sebuah langkahlangkah yang dapat mencakup beberapa materi agardapat dipahami. Algoritma juga dimulai dengan usaha untuk memecahkan permasalahan keputusan yang sudah diajukan.

Adapun salah satu dari algoritma sederhana yaitu menemukan bilangan terbesar dalam sebuah deretan angka yang tak berurut. Dekskripsi nya yaitu :

1. Jika tidak adanya angka dalam deret maka tidak ada pula bilangan paling besar.

2. Pikirkan angka pertama dalam deret merupakan yang terbesar.

3. Untuk setiap angka terakhir dalam deret, dan jika angka terakhir tersebut lebih besar dari pada angka paling besarnya, misal kan saja angka tersebut menjadi angka yang paling besar dalam deret.

4. Lalu yang terakhir jika tidak ada angka yang tersisa lagi untuk diperiksa, anggap menjadi yang terbesar dalam deret.

Jadi, dalam sebuah cakupan materi sebenarnya sudah diatur beberapa langkahlangkah yang bahkan sudah diketahui dengan jelas.

\section{Pengertian Pemrograman}

Pemrograman adalah sebuah langkah menulis, menguji dan mencerna atau memperbaiki dan menanamkan sebua kode yang dapat memperbaiki suatu program didalam komputer. Tujuannya suatu pemrograman ialah untuk melakukan sebuah pemrograman yang didasari perhitungan atau pekerjan yang dapat disesuaikan dengan keinginan pemrogramannya.

Pemrograman juga bisa dibilang dengan suatu seni yang dapat melakukan beberapa sistem tertentu sehingga sangat sering dihubungkan dengan adanya algoritma agar menjadi satu kesatuan perangkat yang utuh dalam sebuah komputer. Bahasa pemrograman sendiri dibuat agarlebih mudah dalam masa era modern zaman sekarang yang sudah semakin banyak teknologi diciptakan.

Pemrograman sendiri juga dibuatatasdasar sebuah misi pelacakan pada zaman dahulu. Sehingga dengan adanya sebuah perangkat pemrograman ini menjadikan sebuah simpanan file perangkat yang menjadi barang bukti jika dimasukkan kedalam jaringan komputer. Dan apabila rusak tidak akan pernah bisa didapatkan kembali hasilnya.

\section{Pengertian Sistem Operasi}

Sistem menurut para ahli, dapat diartikan sebagai berikut ; menurut Ludwig Von Bartalanfy, sistem merupakan seperangkat unsur yang saling terikat dan saling berhubungan. Alasannya karena pada banyaknya sistem tersebut membuat ketergantungan antar sistem satu dengan yang lainnya. Sistem memiliki banyak perangkat yang membuat pengoperasiannya dapat berjalan sebagaimana mestinya. Seperti yang kita tahu bahwa tak hanya komputer tetapi alatalat teknologi dari zaman dahulu hingga 
sekarang memiliki alat-alat yang berbedabeda setiap sitemnya. Contoh lain dari komputer yaitu handphone yang memiliki sangat banyak merk dan selalu memperbaharui fitur-fiturnya agar lebih maksimal menampilkan keunggulannya di kalangan pengguna.

Sistem komputer sangat memiliki banyak keunggulan yaitu bisa lebih unggul daripada handphone karena dengan keunggulan besarnya ataupun bentuk dari komputer itu sendiri. Apalagi jika kita sudah menggunakan komputer atau laptop dengan fitur terbaru atau windows terbaru bisa membuat penggunanya lebih lancar untuk setiap pemakaiannya.

\section{Pengertian Komputer}

Komputer yaitu sebuah benda atau alat yangbanyak digunakan diseluruh penjuru dunia. Dimana setiap orang pada zaman sekarang mempunyai komputer. Apalagi untuk para pekerja sangat tidak mungkin tidak pernah berkutik pada sebuah komputer. Di dunia sekolah, perkuliahan atau pekerjaan membutuhkan sekali yang namanya komputer. Karena kalau tidak pandai memakai komputer akan kalah dengan orang-orang yang sudah mengenal komputer dari masih kecil.

Dalam komputer juga banyak sekali menyimpan jaringan-jaringan, sistem hingga beberapa aplikasi yang bisa digunakan oleh para penggunanya. Contoh nya jika ingin membuka suatu web dengan jelas bisa langsung membuka nya di komputer. Lalu jika ingin melakukan pekerjaan melalui komputer dengan menggunakan microsoft windows, microsoft excel, microsoft power point bisa langsung menggunakan komputer sebagai alat pemandu atau untuk melakukan sesuatu dengan banyak cara. Yaitu jika ingin membuat suatu data dengan menggunakan tabel maka bisa menggunakan microsoft excel agar hasilnya bisa susai dan sangat mudah dipahami dengan jelas.

Karena di dalam komputer sangat banyak sekali yang bisa digunakan. Jadi seperti yang dijelaskan bahwa ada beberapa manfaatdari komputer, yaitu :

1. Jika untuk seorang pelajar atau mahasiswa, komputer sangatlah berguna untuk mengerjakan tugas-tugas ataupun untuk sekedar mencari materi. Apalagi pada masa corona, hampir semua daerah mengadakan sekolah atau kuliah online dimana sangat banyak melibatkan komputer di setiap kegiatannya.

2. Jika untuk kalangan pekerja yang harus melibatkan membuat surat, membuat data-data perusahaan atau meghitung jumlah nilai keuangan, tak jarang pula hampir semuanya menggunakan komputer. Karena hampir semua fitur nya penting untuk para pekerja yang berada dibidang tersebut.

3. Mempermudah akses internet dan akses dalam memuat data. Seperti yang sudah dijelaskan diatas bahwa sistem operasi ataupun jaringannya sudah dibuat sedemikian rupa sehingga dapat menghasilkan suatu alat canggih bernama komputer ini.

Jadi, dapat disimpulkan dari beberapa penjelasan komputer diatas yaitu komputer merupakan sebuah alat yang terdiri dari beberapa perangkat-perangkatnya yang memiliki kualitas yang bagus serta jaringannya yang bagus pula. dan memiliki banyak sekali manfaat jika dihubungkan ke kehidupan sehari-hari kita yang tak luput dari mengakses internet. 


\section{BAHAN DAN METODE}

\section{Pengamatan Langsung (Observasi)}

Penulis sudah melakukan sebuah pencaharian langsung dan melakukan pengamatan tentang algoritma pemrograman, dan sistem operasi komputer. Tak jarang banyak sekali sebuah tulisan yang dapat dibuat penulis menjadi sebuah ringkasan yang jelas dan utuh agar mudah dipahami dari setiap topik-topiknya.

\section{Angket (Kuesioner)}

Penulis melakukan pencaharian tentang membuat suatu angket dan membuatnya menjadi sebuah pertanyaan yangbisa disebarkan ke beberapa orang terdekat contohnya orang tua ataupun saudara. Kemudian angket tersebut diisi dan dikembalikan secepatnya kepada penulis.

\section{Studi Pustaka}

Setelah membuat dan selesai melakukan observasi (pengamatan langsung) dan membuat angket (kuesioner), penulis dapat mencari kembali beberapa tulisan seperti buku tentang algoritma pemrograman sistem operasi komputer, artikel, jurnal dan makalah agar menambah daftar pustaka pada tulisan ini.

\section{HASIL DAN PEMBAHASAN}

Hasil dan pembahasan yang akan dibuat oleh penulis didalam artikel jurnal ini adalah tentang algoritma pemrograman dan sistem operasi yang sudah keluar dalam komputer dari dulu hingga sekarang yaitu Sistem Operasi DOS, Sistem Operasi Windows, Sistem Operasi Linux dan Sistem Operasi MacsOS. Berikut merupakan pembahasan dari sistem operasi wondows.

\section{Algoritma Pemrograman}

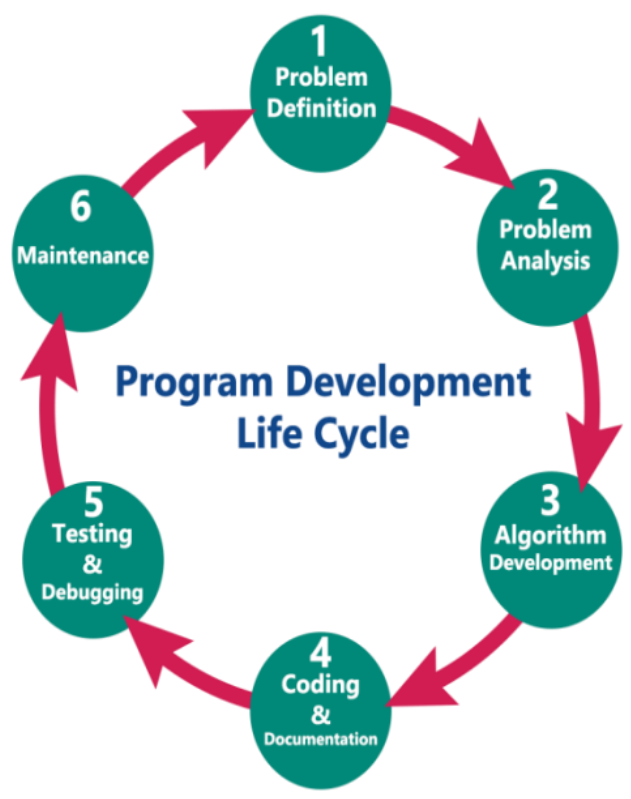

\begin{tabular}{|l|l|l|}
\hline 1. & Problem Defenition & $\begin{array}{l}\text { Proses mengurai dan memahami sesuatu masalah } \\
\text { sedetail-detailnya. Dari proses ini diharapkan kita dapat } \\
\text { memahami inti permasalahan, kebutuhan dan rencana } \\
\text { penyelesaian yang akan dihasilkan. }\end{array}$ \\
\hline 2. & Problem Analys & $\begin{array}{l}\text { Proses menganalisis suatu masalah dengan menentukan } \\
\text { apa yang akan digunakan seperti variabel, fungsi dan } \\
\text { lain-lain. }\end{array}$ \\
\hline 3. & Algorithm Development & $\begin{array}{l}\text { Proses menentukan algoritma dalam proses } \\
\text { menyelesaikan masalah. Fase ini merupakan fase paling } \\
\text { penting dalam tahapan pembuatan program. }\end{array}$ \\
\hline 4. & Coding dan Documentation & $\begin{array}{l}\text { Proses menerjemahkan algoritma kedalam bahasa } \\
\text { pemrograman. Sedangkan proses dokumentasi adalah } \\
\text { proses penulisan tahapan-tahapan proses coding dalam } \\
\text { suatu berkas agar bisa ditinjau di kemudian hari. }\end{array}$ \\
\hline 5. & Testing & $\begin{array}{l}\text { Proses pengujian apakah program yangtelah ditulis dapat } \\
\text { menyelesaikan permasalahan dengan melihat input dan } \\
\text { output dari program. }\end{array}$ \\
\hline 6. & maintenance & $\begin{array}{l}\text { Proses perbaikan jika program mengalami error dan } \\
\text { akan membawa kembali ke desain dan pengembangan } \\
\text { algoritma. }\end{array}$ \\
\hline
\end{tabular}




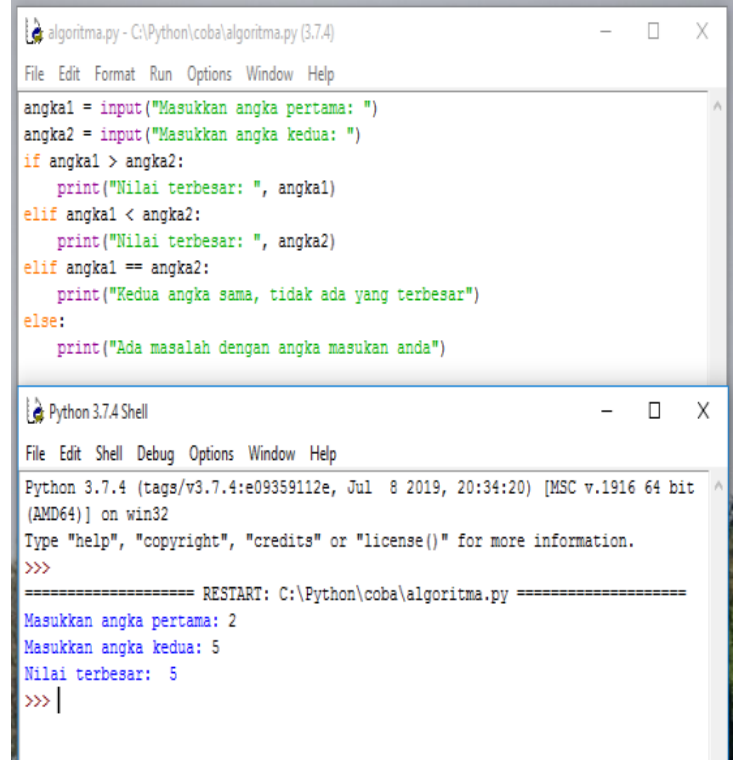

Tahapan pembuatan program :

Mendefenisikan masalah dan menganalisanya. Didalamnya harus terdapat : tujuan pembuatan program, parameter yang digunakan, fasilitas yang disediakan, algoritma yang diterapkan dan bahasa program yang digunakan.

\section{Contoh 1 : Mengitung luas segitiga}

Diketahui nilai alas $=10$ dan tinggi $=8$.

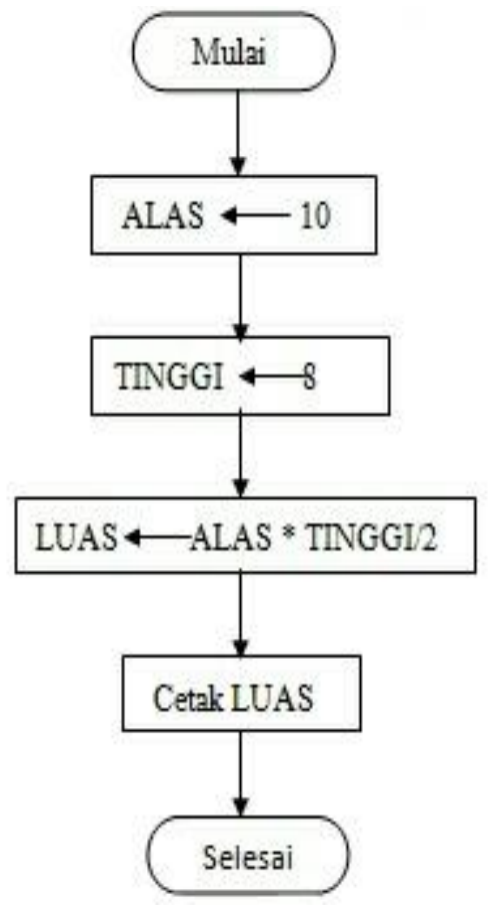

\section{Keterangan :}

1) Memberi harga ALAS sebesar10

2) Memberi harga tinggi sebesar 8

3) Menghitung dan memberi harga LUAS sebesar harga (ALAS x TINGGI) / 2

4) Mencetak harga LUAS (akan tercetak $=40$ )

\section{Contoh 2 : Mencari nilai X}

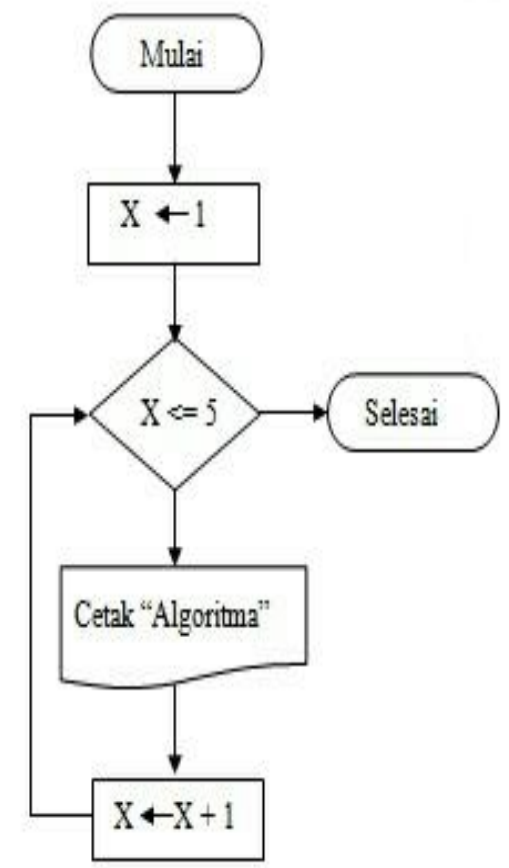

\section{Keterangan :}

1) Memberikan nilai awal $X=1$

2) Melakukan pengecekan nilai $X=5$, jika iya lakukanlah langkah yang ke (3), jika tidak $(X>5)$ maka selesai

3) Cetak kata "Algoritma"

4) Nilai $X$ yang baru sekarang adalah nilai $X$ lama ditambah 1

5) Kembali ke langkah (2) 


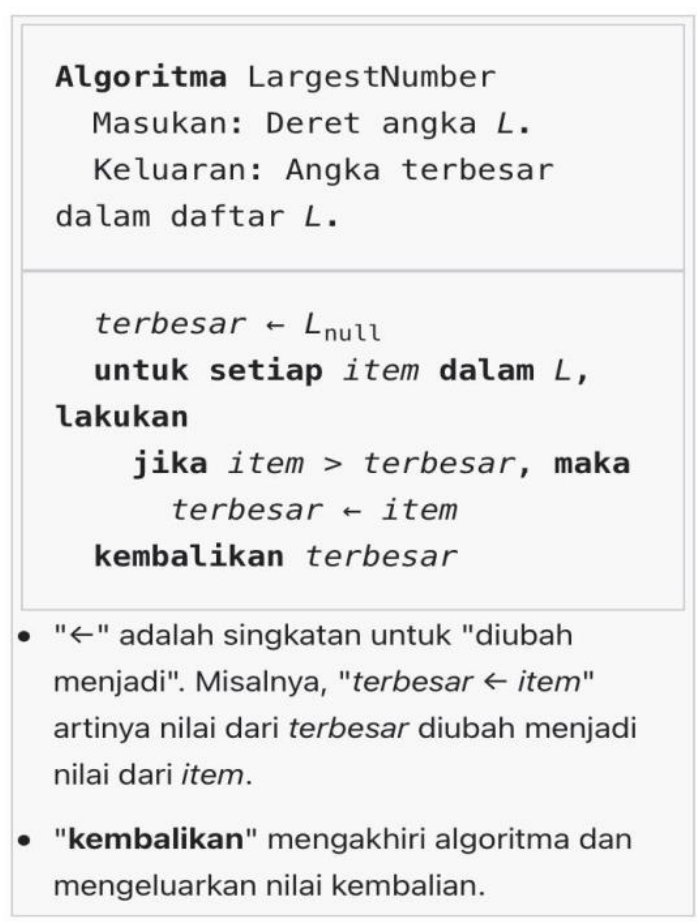

\section{Contoh 3 : Algoritma Narasi}

Algoritma kelulusan mahasiswa

Soal : Dimuat beberapa data yang berisikan nama dan nilai dari mahasiswa. Jika nilai mahasiswa lebih besar atau sama dengan 50 maka dinyatakan lulus. Sedangkan, bila nilainya lebih rendah dari 50, jadi mahasiswa tersebut terbilang tidak akan lulus. Algoritma nya sebagai berikut :

Ingat dan bacalah nama dan nilai dari beberapa mahasiswa tersebut.

Jika nilai > : 50 jadi

keterangannya $=$ lulus

tapi jika nilai $<50$

keterangan $=$ tidak lulus.

\section{Sistem Operasi Komputer}

\section{Sistem Operasi DOS}

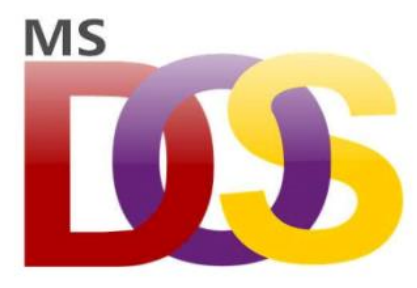

DOS merupakan singkatan dari (Disk Operating System) yang merupakan awal dan paling pertama dalam pembuatan sistem operasi komputer yang digunakan. Seperti yang dibayangkan tampilan DOS ini tidak seperti versi sekarang yang serba ada dari segi manapun. Namun versi ini masih menayangkan layar hitam putih dan belum bisa ada gambar yang ditampilkan. Jadi bisa dikatakan bahwa sistem operasi DOS ini hanyalah proses perangkat pertama dalam komputer.

\section{Kelebihan Sistem Operasi DOS}

- Ringan sehingga tidak menghabiskan banyak memori

- Ukurannya kecil

- Memiliki kompatibilitas tinggi

\section{Kekurangan Sistem Operasi DOS}

- Belum ada antar muka

- Instruksinya hanya berupa tulisan tidak ada grafis

\section{Sistem Operasi Windows}

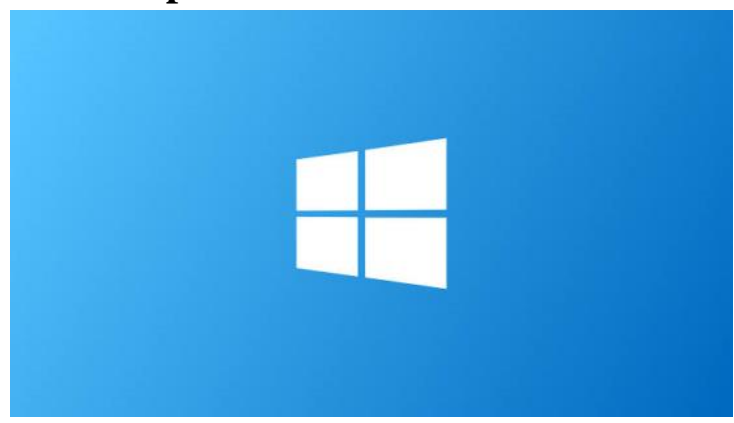

Sistem operasi windows ini adalah operasi yang paling banyak digunakan di seluruh penjuru negeri karena banyak manfaatnya dan banyak membantu kehidupan sehari-hari seperti pekerjaan dan akademik hingga kebutuhan pribadi dirumah. Dimasa sekarang, windows merupakan salah satu yangterbaik daripada sistem operasi yang lainnya dan merupakan salah satu yang paling banyak digunakan oleh para pengguna komputer. 
Tak hanya banyak manfaatnya, windows mengalami banyak pengembangan terutama dalam tampilan programnya yang pastinya lebih baik daripada sistem operasi DOS. Dan windows juga sudah terpasang dihampir seluruh pengguna komputer di berbagai merk yang telah diperjual belikan.

\section{Kelebihan sistem operasi windows}

- Tampilan antarmuka userfriendly

- Lebih mudah dalam prses instalasi

- Aplikasi OS windows melimpah

\section{Kekurangan sistem operasi windows}

- Tidak open surce

- Berbayardan lumayan mahal

- Mudah diretas karena sistem keamanannya masih lemah

- Rentan terkena serangan virus

\section{Sistem Operasi Linux}

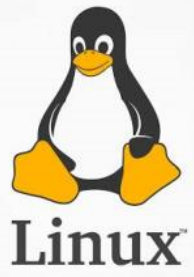

Linux diperkenalkan oleh khayalak ramai pada tahun 1991. Dapat dikatakan bahwa sistem operasi linux ini sedikit berbeda daripada yang lain karena dapat diubah dan didistribusikan kembali secara terbuka tanpa perlu pertimbangan kepada sistem operasinya. Para penggunanya biasanya lebih paham akan teknologi, oleh karena itu linux bisa diubah-ubah menjadi sistem baru oleh para penggunanya.

\section{Kelebihan sistem operasi linux}

- Open surce

- Gratis dan tidak ada biaya lisensi

- Perkembangannya sangat kencang karena dikembangkan banyak orang

Kekurangan sistem operasi linux

- Tidak dianjurkan bagi pengguna awam

- Aplikasi linux terbatas

- Cara instal linux terbilang susah

\section{Sistem Operasi MacOS}

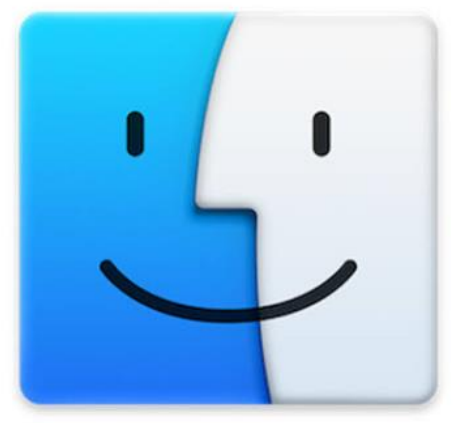

Sistem Operasi macOS (Machintosh Operating Sysitem) yaitu sistem yanghanya berkontribusi pada produk Apple saja. Diperkenalkan pada tahun 1984 dan langsung digunakan pada salah satu komputer.

Sistem MacOS ini memang jarang dimiliki oleh terpilih di beberapa pengguna. Karena seperti yang kitatahu bahwa produk apple masih tergolong lebih mahal daripada produk-produk komputer, laptop, smartphone lainnya. 


\section{Kelebihan sistem operasi macOS}

- Lebih stabil

- Tampilan antar muka cocok untuk kebutuhan multimedia

- Memiliki keamanan tinggi dan tidak mudahdiretas

- Aman dari virus

\section{Kekurangan sistem operasi macOS}

- Harganya relatif mahal

- Kurang optimal untuk gaming

- Tidak open source

\section{Sistem Operasi UNIX}

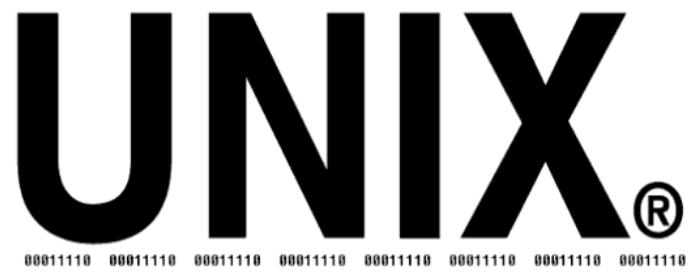

Hampir sama seperti DOS, sistem operasi ini adalah produk sistem lama yang termasuk banyak digunakan pada masa terdahulu yang menjadi salah satu awalan pembuatan OS pada zaman sekarang. UNIX juga memiliki banyak sekali versi yang bia dipilih oleh penggunanya berdasarkan versi yangtelah dibuat.

Kelebihan sistem operasi UNIX

- Tidak mudah terkena virus

- Gratis dan bisa digunakan CumaCuma

\section{Kekurangan sistem operasi UNIX}

- Tampilan UNIX kurangmenarik

- Tidak memiliki banyak pilihan driver

\section{KESIMPULAN}

Algoritma adalah prosedur langkah demi langkah untuk suatu perhitungan. Algoritma digunakan untuk penghitungan, pemrosesan data dan penalaran otomatis. Jadi algoritma bisa dibilang sebuah jalan untuk mencapai tujuannya. Pemrograman adalah sebuah langkah menulis, menguji dan mencerna atau memperbaiki dan menanamkan sebua kode yang dapat memperbaiki suatu program didalam komputer. Tujuannya suatu pemrograman ialah untuk melakukan sebuah pemrograman yang didasari perhitungan atau pekerjan yang dapat disesuaikan dengan keinginan pemrogramannya.

Sistem komputer sangat memiliki banyak keunggulan yaitu bisa lebih unggul daripada handphone karena dengan keunggulan besarnya ataupun bentuk dari komputer itu sendiri. Apalagi jika kita sudah menggunakan komputer atau laptop dengan fitur terbaru atau windows terbaru bisa membuat penggunanya lebih lancar untuk setiap pemakaiannya.

Komputer yaitu sebuah benda atau alat yangbanyak digunakan diseluruh penjuru dunia. Dimana setiap orang pada zaman sekarang mempunyai komputer. Apalagi untuk para pekerja sangat tidak mungkin tidak pernah berkutik pada sebuah komputer. Di dunia sekolah, perkuliahan atau pekerjaan membutuhkan sekali yang namanya komputer. Karena kalau tidak pandai memakai komputer akan kalah dengan orang-orang yang sudah mengenal komputer dari masih kecil.

Maka dari itu penggunaannya bisa dihubungkan menjadi salah satu peranan dalam sistem operasi dimana didalamnya 
terdapat algoritma pemograman. Sistem operasi merupakan peranan yang sangat penting dalam berbagai perangkatperangkat yang ada dalam komputer. Karena pada dasarnya sebuah komputer juga didasarkan oleh sebuah sistem operasi yang sudah pasti sangat canggih perkembangannya yang tak lain dan tak bukan yaitu sistem perangkat lunak (software), perangkat keras (hardware) dan pengguna (brainware). Contoh dari perangkat lunak (software) yaitu microsoft office yang sangat sering sekali dipakai oleh kalangan pelajar ataupun pekerja.

Seperti yang kita ketahui juga bahwa banyak sekali materi pada matematika bisa dikaitkan atau sangat berhubungan kedalam kehidupan seharihari. Oleh karena itu kesimpulannya ialah algoritma merupakan sebuah langkahlangkah yang dapat mencakup beberapa materi agar dapat dipahami. Algoritma juga dimulai dengan usaha untuk memecahkan permasalahan keputusan yang sudah diajukan.

Banyak sekali sistem atau jaringan yang adadalam komputer, tetapi zaman juga semakin berkembang darei waktu kewaktu. Oleh karena itu hanya beberapa saja yang dapat diketahui dengan jelas, serta asal-usul pembuatan, tahunnya dapat diketahui. Bahkan salah satu dari sistem operasi yang telah dijelaskan sempat dihubungkan langsung ke salah satu perangkat pertama yang bernama "LISA". Bentuknya seperti smartphone tetapi jelas memiliki perbedaaan yang sangat rinci yaitu dari segi penampilan, gambar serta warna dari layarnya.

sistem operasi yang sudah keluar dalam komputer dari dulu hingga sekarang yaitu
(Sistem Operasi DOS) Yaitu sistem yang pertama kali diperlihatkan kepada dunia untuk memenuhi persyaratan dari sistem komputer, (Sistem Operasi Windows) yaitu sistem paling terkenalnya adalah windows 8 dan 10. Di mana hingga zaman sekarang pun sistem operasi ini masih menjadi penggemar peringkat pertama bagi penggunanya, (Sistem Operasi Linux) tak kalah dengan windows dari segi pengaturan dan kebijakan, hanya saja operasi linux ini hanya dipakai oleh orang-orang yang lebih paham akan teknologi komputer. Jadi tidak sembaran orang yang bisa menjadi penggunanya. dan (Sistem Operasi MacsOS) yaitu sistem operasi komputer yang hanya bisa digunakan oleh produkproduk Apple saja. Dan sangat jarang digunakan karena MacOS Tersebut memiliki harga jual yang terbilang sangat tinggi.

Banyaknya sistem operasi komputer yang telah diterbitkan dari tahun ke tahun. Tak jarang pula setiap tahunnya komputer mengeluarkan produk-produk dan jaringan yang lebih ter perbaharui. Logikanya, jika ingin mempelajari tentang algoritma dan pemrograman akan lebih baik jika menggunakan sistem operasi windows 10 . Karena hampir seluruh perangkatnya telah mencapai perbaharui level maksimal dan tujuaannya juga agar pengguna lebih mudah menggunakannya dan dapat dengan mudah melakukan pekerjaan dengan komputer. Meski begitu, setiap tahun terbit dari semua sistem operasi komputer selalu mempunyai keunggulannya masingmasing. Karena telah dikerjakan dengan sebaik mungkin dan semaksimal mungkin.

\section{DAFTAR BACAAN}


Suharyanto, Cosmas Eko.2016.Analisis

Komparatif Sistem Keamanan Windows 7 Dan Windows 8,Vol.4 Nomor 1.Halaman 1-21.

Yafizham, St.,M.Cs.Analisis Waktu Algoritma Quicksort Dan Mergesort. Halaman 1-3.

Budiman, Edi.2015.Belajar Dasar Algoritma Dan Pemrograman. Samarinda : Indonesia Publishing House.

Suryadi, Dkk. 1997. Pengantar Algoritma Dan Pemrograman Teknik Diagram Alur Dan Bahasa Basic Dasar. Pondokcina, Depok :Gunadarma.

Maulana, Gun Gun. 2017. Pembelajaran Dasar Algoritma Dan Pemrograman Menggunakan El-Goritma Berbasis Web. Vol.06. Halaman 69-73.

Saniman, Dkk. 2008. Pengantar Algoritma Dan Pemrograman. Vol.4 No.1. Halaman 120-133.
Retta, Allen Marga. Dkk. 2016. Pengaruh Penerpan Algoritma Terhadap Pembelajaran Pemrograman Komputer. Volume 2 No.2. Halaman 126-135.

Udayana, Kadek Bagus Feristha. 2018. Penerapan Komponen Dan Strukturalgoritma Pada Algoritma Dan Pemrograman Dasar. Volume 5 Nomor 1. Halaman : 38-42.

Rajab, Abdul. 2007. Algoritma Pemrograman Komputer Berdasarkan Metode Penyelesaian Analitis Terhadap Persoalan Dispatch Ekonomi. Volume 01 Nomor 28. Halaman: 102-107.

Marisa, Fitri. 2008. Pengembangan Web Based Learning Dalam Mata Kuliah Algoritma Pemrograman 1 Di Stmik Pradnya Paramitha Malang. Volume 3 Nomor 1. Halaman:14-1. 